\title{
Стан нюхової функції та іії вплив на якість життя пацієнтів залежно від порушення прохідності носових ходів
}

\author{
В.О. Шкорботун, М.О. Овсієнко
}

Національний університет охорони здоров'я України імені П.Л. Шупика, Київ, Україна

\begin{abstract}
Анотація. Важливою складовою дослідження якості носового дихання $\epsilon$ визначення не лише кількісних показників проходження повітря через ніс, а й суб'єктивні відчуття задоволеності таким диханням. Відомі випадки порушення якості життя пацієнтів за рахунок синоназальних симптомів при вільному носовому диханні й опору повітря в носових ходах в межах норми. Мета: з'ясувати вплив нюхової рецепції на задоволеність пацієнтів якістю життя і дихальної функції носа залежно від порушення прохідності носових ходів. Об'єкт і методи дослідження. Обстежено 75 пацієнтів, що звернулися зі скаргами на порушення дихання носом та/або були незадоволені якістю носового дихання. В усіх обстежених проведено дослідження якості життя за опитувальником SNOT=22, виконані комп'ютерна риноманометрія та ольфактометрія за тестами «Sniffin' Sticks». Висновок. Однією з причин незадоволеності якістю носового дихання пацієнтів при нормальних показниках загального опору проходження повітря $\left(\mathrm{R}_{150 \text { (заг) }}<0,25\right.$ Па/см³/c) може бути дисфункція нюхового рецептора (гіпосмія та аносмія), яка виявляється порушенням не лише розпізнавання запахів та гостроти сприйняття, а й формування суб'єктивного відчуття у хворого задоволеності дихання носом і якістю життя.

Ключові слова: носове дихання, нюхова функція, дизосмія, риноманометрія, SNOT-22.
\end{abstract}

\section{Вступ}

3 розвитком сучасної медицини все більшого значення набувають дослідження якості життя пацієнтів, що базуються не лише на об'єктивних кількісних показниках, а й на суб'єктивних відчуттях. Оцінка якості життя та задоволення пацієнтів різними видами лікування дозволяє отримати більше інформації про лікувальнодіагностичний процес і сприяє пошуку нових можливостей щодо підвищення ефективності лікувальних технологій [1].

Носове дихання - унікальний і складний фізіологічний процес, при якому реалізується одразу декілька функцій. При вдиханні певного об'єму повітря через ніс вмикаються механізми його очищення, зігрівання, зволоження та інші адаптивні реакції організму. Важливою складовою серед них $\epsilon$ нюхова рецепція запахів з тригерною системою регулювання виділення слизу та інших функцій слизової оболонки порожнини носа.

Найбільш популярні тести для визначення якості життя пацієнтів із синоназальними захворюваннями - це шкала ефективності септопластики при закладеності носа (Nasal obstructive symptom evaluation - NOSE) [2], тест на синоназальні наслідки (Sinonasal outcomes test - SNOT)-20 [3] та SNOT-22 [4], що включає додатково запитання з вивчення закладеності носа та відчуття смаку і сприйняття запахів.

Для оцінки дихальної функції носа в сучасних умовах використовують різні методики риноманометрії, основними показниками якої $\epsilon$ визначення опору та об'єму проходження повітря через носові ходи. Риноманометрія з комп'ютерною обробкою даних дозволяє визначити й інші критерії, зокрема розрахунок загального опору за результатами окремо визначеного тиску в обох половинах носа, тиск на різних рівнях проходження повітря через носові ходи, встановити межу переходу ламінарного потоку повітря в турбулентний, що $є$ надзвичайно важливим для визначення кондуктивної патології нюхового рецептора [5].

Для вивчення нюхової функції існують різні методи ії дослідження, від опитувальників з вивчення порушення нюху (Questionnaire of olfactory disorders - QOD) [6] до складних об'єктивних тестів $[7,8]$. Одним із сучасних методів ольфактометрії $\epsilon$ набір психофізичних тестів «Sniffin' Sticks» («Burghardt”, Німеччина) [9] в різних модифікаціях, за допомогою яких визначається поріг сприйняття та розпізнавання запахів. Цей інструмент оцінки нюхової функції пройшов валідацію в багатьох європейських країнах і рекомендується Європейським консенсусом (position paper) для клінічного дослідження ольфакторної дисфункції [10].

При аналізі літератури з вивчення окремо дихальної та окремо нюхової функцій носа виявлено значну кількість публікацій [11-16], але інформації про вплив нюхової рецепції на якість життя і рівень задоволеності пацієнтів носовим диханням при різних показниках дихальної функції носа ми не знайшли.

Мета дослідження: з'ясувати вплив нюхової рецепції на задоволеність пацієнтів якістю життя і дихальною функцією носа залежно від порушення прохідності носових ходів.

\section{Об'єкт і методи дослідження}

На базі отоларингологічного відділення КНП «Київська міська клінічна лікарня № 9» (клінічна база кафедри оториноларингології Національного університету охорони здоров'я України імені П.Л. Шупика) обстежено 75 пацієнтів, що звернулися зі скаргами на порушення носового дихання та/або були незадоволені якістю носового дихання. Вік пацієнтів - 15-51 рік $(32,9 \pm 7,4$ року), 3 яких 37 (49,3\%) жінок та 38 (50,7\%) чоловіків.

3 метою виключення перцептивного порушення нюхової функції чи наслідків синоназальних алергологічних проявів в усіх обстежуваних оцінювали алергологічний та неврологічний статус. Для зменшення вираженості впливу запальних процесів у слизовій оболонці всі учасники дослідження пройшли 4-тижневий курс лікування інтраназальними кортикостероїдами (мометазону фуроат). Крім того, критеріями виключення були пухлини порожнини носа та приносових синусів.

Окрім вивчення анамнестичних даних та загального оториноларингологічного обстеження, всім пацієнтам проведено опитування щодо якості життя при порушенні носового дихання та сприймання запахів за опитувальником SNOT-22, риноманометрію та ольфактометрію.

Опитування щодо якості носового дихання здійснювали за опитувальником SNOT-22 у валідованій україномовній верciї [17]. Отримані результати оцінювали за кількістю набраних балів при анкетуванні: норма $-<8$, легкий ступінь $-8-20$, середній $-21-50$ і тяжкий — $>50$ балів $[18,19]$.

Оцінку дихальної функції здійснювали за методикою передньої активної ринометрії (ПАРМ) з використанням риноманометра «OPTIMUS», Україна (свідоцтво державної реєстрації № 14777/2015). При цьому визначали опір при проходженні повітря окремо через кожну половину носа на тиску $\mathrm{R}_{150}\left(П \mathrm{la} / \mathrm{cm}^{3} / \mathrm{c}\right)$ з розрахунком загального опору $\mathrm{R}_{150 \text { (заг). }}$ Загальний опір повітря при тиску 150 Па $<0,25$ Па/см³/с прийнятий за норму, підвищення загального опору $\geq 0,25$ розцінювали як порушення носового дихання [20,21].

Ольфактометрію проводили із застосуванням набору психофізичних тестів «Sniffin” Sticks» («Burghardt”», Німеччина) для визначення порогу нюху та розпізнавання запахів. Набір включає багаторазо- 
ві маркери з різними запахами. Дослідження виконували для обох половин носа разом. Розпізнавання запахів визначали за допомогою альтернативних візуальних сигналів примусового вибору й оцінювали в балах: нормосмія - 12-11, гіпосмія - 10-7, аносмія - <7 балів [22].

Статистичну обробку отриманих результатів здійснювали за допомогою методів варіаційної статистики з використанням точного критерію Фішера та Манна - Уїні [23].

\section{Результати та їх обговорення}

За результатами тестування пацієнтів за опитувальником SNOT22 здійснено їх розподіл та ранжування відповідно до ступеня погіршення якості життя (табл. 1).

Дані, наведені утабл. 1, свідчать, що у 56,0\% хворих за результатами анкетування встановлено легкий ступінь порушення якості життя, у 23 (30,7\%) - середній, у 10 (13,3\%) - тяжкий.

Дані щодо віку та статі обстежених пацієнтів представлені у табл. 2.

Згідно 3 даними табл. 2 середній вік пацієнтів становив $32,9 \pm 7,4$ року і за групами суттєво не відрізнявся. Щодо розподілу за статтю: жінок 37 (49,3\%), чоловіків - 38 (50,7\%). Зазначимо, що в групі пацієнтів з легким ступенем порушення якості життя чоловіків виявилося більше, ніж жінок, - 25 (59,5\%) та 17 (40,5\%) відповідно.

Показники дихальної функції носа залежно від ступеня порушення якості життя представлені в табл. 3.

Таблиця 1 Розподіл пацієнтів на групи за результатами анкетування за SNOT-22

\begin{tabular}{|c|c|c|c|c|}
\hline & \multicolumn{4}{|c|}{ Ступінь порушення якості життя за SNOT-22 } \\
\hline & $\begin{array}{c}\text { Легкий } \\
\text { (8-20 балів) }\end{array}$ & $\begin{array}{c}\text { Середній } \\
\text { (21-50 балів) }\end{array}$ & $\begin{array}{c}\text { Тяжкий } \\
\text { (>50 балів) }\end{array}$ & Всboro \\
\hline Група & 1-ша & 2-ra & 3-тя & \\
\hline $\mathrm{n}(\%)$ & $42(56,0)$ & $23(30,7)$ & $10(13,3)$ & $75(100)$ \\
\hline
\end{tabular}

Таблиця 2 Розподіл пацієнтів за віком та статтю залежно від ступеня порушення якості життя

\begin{tabular}{lccc}
\hline \multirow{2}{*}{ Група } & \multicolumn{2}{c}{ Вік } & \multicolumn{2}{c}{ Стать } \\
\cline { 2 - 4 } & $\mathbf{M} \pm \mathbf{m}$ & Жінки, $\mathbf{n}(\%)$ & Чоловіки, $\mathbf{n}(\%)$ \\
\hline 1-ша $(\mathrm{n}=42)$ & $33,02 \pm 7,75$ & $17(40,5)$ & $25(59,5)$ \\
\hline 2-га $(\mathrm{n}=23)$ & $33,73 \pm 7,99$ & $14(60,9)$ & $9(39,1)$ \\
\hline 3-тя $(\mathrm{n}=10)$ & $31,00 \pm 3,82$ & $6(60,0)$ & $4(40,0)$ \\
\hline Всього $(\mathrm{n}=75)$ & $32,90 \pm 7,40$ & $37(49,3)$ & $38(50,7)$ \\
\hline
\end{tabular}

Таблиця 3 Результати дослідження загального опору повітряному потоку залежно від ступеня порушення якості життя пацієнтів

\begin{tabular}{|c|c|c|}
\hline \multirow{3}{*}{ Група } & \multicolumn{2}{|c|}{$\begin{array}{l}\text { Загальний опір повітряному потоку, за даними } \\
\qquad \begin{array}{l}\text { ПАРM R } \\
150\end{array}\left(\Pi \mathrm{a} / \mathrm{cm}^{3} / \mathrm{c}\right)\end{array}$} \\
\hline & $<0,25$ & $\geq 0,25$ \\
\hline & n (\%) & n (\%) \\
\hline 1-ша $(n=42)$ & $42(100,0)$ & - \\
\hline 2-га $(n=23)$ & $2(8,7)$ & $21(91,3)$ \\
\hline 3-тя $(n=10)$ & - & $10(100,0)$ \\
\hline Всього $(n=75)$ & $44(58,7)$ & $31(41,3)$ \\
\hline
\end{tabular}

Дані табл. 3 свідчать, що у 44 (58,7\%) осіб опір при проходженні повітря через ніс становив $\mathrm{R}_{150 \text { (заг) }}<0,25$ Па/см³/с, а у 31 обстеженого виявлено порушення прохідності носових ходів $3 \mathrm{R}_{150 \text { (заг) }} \geq 0,25$ Па/ $\mathrm{cm}^{3} /$ с. Певний взаємозв'язок між цими показниками прослідкову$\epsilon$ сься, але залишається незрозумілим факт, чому пацієнти із загальним опором повітря в носових ходах при ПАРМ $\mathrm{R}_{150}<0,25$ Па/ $\mathrm{cm}^{3} / \mathrm{c}$, що свідчить про досить вільне носове дихання, скаржаться на порушення якості життя внаслідок незадоволеності носовим диханням. Виникає таке припущення: можливо, задоволеність якістю носового дихання залежить не лише від вільного дихання через ніс, а й від порушення інших функцій носа, зокрема нюхової рецепції. Ольфакторна дисфункція може бути однією зі складових формування відчуття задоволеності носовим диханням.

Результати ольфактометрії у хворих залежно від ступеня порушення якості життя пацієнтів за опитувальником SNOT-22 представлені в табл. 4 та у вигляді діаграми на рисунку.

Рисунок Розподіл пацієнтів з різними варіантами сприйняття запахів залежно від якості життя згідно з опитуванням SNOT-22

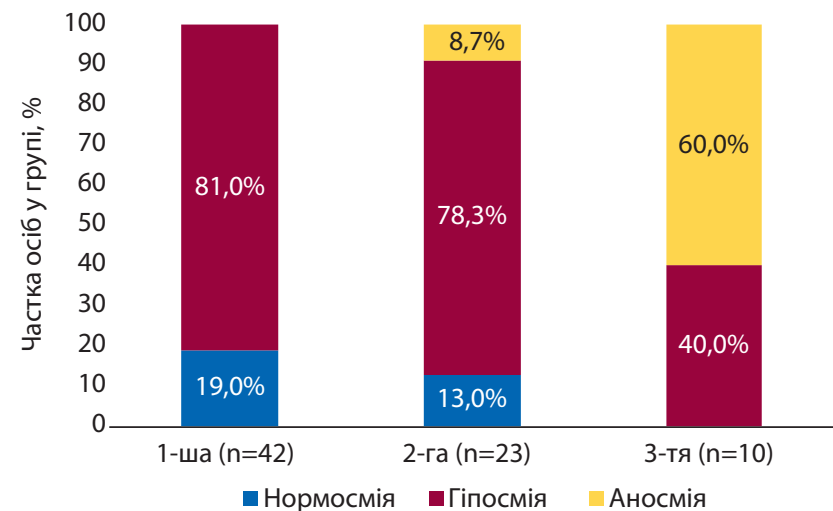

Дані, наведені у табл. 4, свідчать, що з 75 обстежених лише у 11 (14,7\%) встановлена нормосмія, у інших 64 (85,3\%) виявлена дизосмія різного ступеня, серед них у 56 (74,6\%) - гіпосмія з серед-

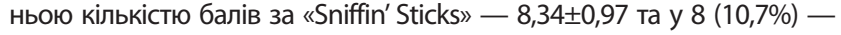
аносмія $(5,62 \pm 0,51)$. Звертає на себе увагу той факт, що у більшості пацієнтів з легким ступенем порушення якості життя - 34 (81\%) -

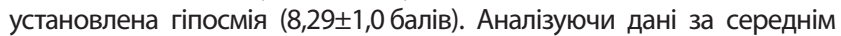
балом при ольфактометрії по групах залежно від ступня порушення якості життя, виявлено достовірно гірші показники сприймання запахів у осіб із суттєвим порушенням якості життя за результатами опитування SNOT-22 (3-тя група) в порівнянні з іншими групами опитуваних.

Дані щодо впливу дихальної функції носа за показником загального опору повітряному потоку при ПАРМ на нюхову рецепцію представлені в табл. 5.

Як зазначено у табл. 5, у пацієнтів із підвищеним опором проходження повітря через ніс $\left(R_{150} \geq 0,25\right.$ Па/ $\left.\mathrm{cm}^{3} / c\right)$ у 90,3\% випадків виявлено порушення нюхової функції і лише у 3 (9,7\%) обстежених встановлена нормосмія. При цьому в групі пацієнтів з $\mathrm{R}_{150}<0,25$ Па/см³/c гіпосмія зареєстрована у 81,8\% обстежених, а у інших 18,2\% - нормосмія. Слід відмітити, що частка осіб з аносмією суттєво вища у групі з підвищеним опором проходження повітря через ніс ( $<<0,05)$.

Аналізуючи показники якості життя пацієнтів за SNOT-22 залежно від показників загального опору повітря в носових ходах

Таблиця 4 Дані ольфактометричного обстеження хворих залежно від порушення якості життя за SNOT-22

\begin{tabular}{|c|c|c|c|c|c|c|c|}
\hline \multirow{3}{*}{ Групи пацієнтів } & \multicolumn{6}{|c|}{ Показники ольфактометрії за «Sniffin' Sticks» (у балах) } & \multirow{3}{*}{ 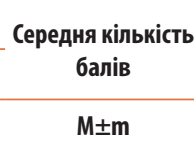 } \\
\hline & \multicolumn{2}{|c|}{ Нормосмія (11-12) } & \multicolumn{2}{|c|}{ Гіпосмія (7-10) } & \multicolumn{2}{|c|}{ Аносмія (<7) } & \\
\hline & n (\%) & $M \pm m$ & n (\%) & $M \pm m$ & n (\%) & $M \pm m$ & \\
\hline 1-ша $(n=42)$ & $8(19)$ & $11,25 \pm 0,46$ & $34(81)^{*}$ & $8,29 \pm 1,0$ & $-{ }^{*}$ & - & $8,85 \pm 1,5^{*}$ \\
\hline $2-г а(n=23)$ & $3(13)$ & $11,66 \pm 0,57$ & $18(78,3)^{* *}$ & $8,61 \pm 0,84$ & $2(8,7)^{* *}$ & $5,5 \pm 0,7$ & $8,73 \pm 1,65^{* *}$ \\
\hline 3-тя $(n=10)$ & - & - & $4(40)^{*, * *}$ & $7,5 \pm 0,57$ & $6(60)^{*, * *}$ & $5,66 \pm 0,51$ & $6,4 \pm 1,07^{*, * *}$ \\
\hline Всього $(n=75)$ & $11(14,7)$ & $11,36 \pm 0,5$ & $56(74,6)$ & $8,34 \pm 0,97$ & $8(10,7)$ & $5,62 \pm 0,51$ & $8,49 \pm 1,7$ \\
\hline
\end{tabular}

${ }^{*} p_{1-3}<0,05 ; * * p_{2-3}<0,05$. 
Таблиця 5 Результати ольфактометрії залежно від опору проходження повітря через ніс

\begin{tabular}{|c|c|c|c|}
\hline \multirow{3}{*}{$\begin{array}{c}\text { Показник загального опору } \\
\text { проходження повітря через } \\
\text { ніс в Па } / \mathrm{cm}^{3} / \mathrm{c}\end{array}$} & \multicolumn{3}{|c|}{ Ольфактометрія за тестуванням «Sniffin' Sticks» } \\
\hline & Нормосмія & Гіпосмія & Аносмія \\
\hline & n (\%) & n (\%) & n (\%) \\
\hline$R_{150}<0,25(n=44)$ & $8(18,2)$ & $36(81,8)$ & $0(0,0)^{*}$ \\
\hline$R_{150} \geq 0,25(n=31)$ & $3(9,7)$ & $20(64,5)$ & $8(25,8)^{*}$ \\
\hline Всього $(n=75)$ & $11(14,6)$ & $54(74,7)$ & $8(10,7)$ \\
\hline
\end{tabular}

(ПАРМ $\left.\left(\mathrm{R}_{150 \text { (заг) }}\right)\right)$ та показників ольфактометрії, можна зробити висновок, що пацієнти не завжди задоволені носовим диханням при вільному проходженні повітря через ніс $\left(\mathrm{R}_{150}<0,25 \Pi \mathrm{\Pi a} / \mathrm{cm}^{3} / \mathrm{c}\right)$.

\section{Висновки}

1. Із 75 пацієнтів, які скаржилися на незадовільну якість носового дихання, у 58,7\% опір повітря в носових ходах становив $<0,25 \Pi а / \mathrm{cm}^{3} /$ с щ що вказує на їх достатню прохідність.

2. За даними ольфактометрії, із 44 пацієнтів зі скаргами на незадовільну якість носового дихання при загальному опорі повітря в носових ходах $\mathrm{R}_{150 \text { (заг) }}<0,25 \mathrm{Па} / \mathrm{cm}^{3} /$ с у $34(81,8 \%)$ виявлена дизосмія різного ступеня.

3. Однією з причин незадоволеності якістю носового дихання пацієнтів при нормальних показниках загального опору $\left(\mathrm{R}_{150 \text { (заг). }}<0,25 \Pi \mathrm{a} / \mathrm{cm}^{3} / \mathrm{c}\right)$ може бути дисфункція нюхового рецептора (гіпосмія та аносмія), яка проявляється не лише порушенням розпізнавання запахів та гостроти сприйняття, а й порушенням формування суб'єктивного відчуття у хворого задоволеності дихання носом і якістю життя.

\section{Список використаної літератури}

1. Rimmer J., Hellings P., Lund V. et al. (2019) European position paper on diagnostic tools in rhinology. Rhinol.j., 57(S28): 1-41.

2. Stewart M., Witsell D., Smith T. et al. (2004) Development and Validation of the Nasal Obstruction Symptom Evaluation (NOSE) Scale. Otolaryngol. Head Neck Surg., 130(2): 157-163.

3. Piccirillo J., Merritt M., Richards M. (2002) Psychometric and Clinimetric Validity of the 20-Item SinoNasal Outcome Test (Snot-20). Otolaryngol. Head Neck Surg., 126(1):41-47.

4. Hopkins C., GillettS.,SlackR.etal. (2009) Psychometricvalidity of the 22-item Sinonasal OutcomeTest. Clin. Otolaryngol., 34(5): 447-454.

5. Gelardi M.,Piccininni K., Quaranta N. etal. (2019) Olfactory dysfunction in patients with chronic chinosinusitis with nasal polyps is associated with clinical-cytological grading severity. Acta Otorhinolaryngol. Ital., 39(5):329-335.

6. Frasnelli J., Hummel T. (2004) Olfactory dysfunction and daily life. Eur. Arch. Oto-Rhino-Laryngol., 262(3):231-235.

7. Mozzanica F., Preti A., Gera R. et al. (2019) Quality of life impairment and its assessment in patients with olfactory dysfunction. Otorinolaringol.,69(3).

8. Morley A., Sharp H. (2006) A review of sinonasal outcome scoring systems — which is best? Clin Otolaryngol., 31(2): 103-109.

9. Hummel T., Sekinger B., WolfS. et al. (1997) «Sniffin' Stickss): Olfactory Performance Assessed by the Combined Testing of Odour Identification, Odor Discrimination and Olfactory Threshold. Chemical Senses, 22(1):39-52

10. Hummel T., Whitcroft K., Andrews P. et al. (2017) Position paper on olfactory dysfunction. Rhinol. J., 54(26): $1-30$.

11. Magliulo G., DeVincentiis M., lannella G. et al. (2018) Olfactory evaluation in obstructive sleep apnoea patients. Acta Otorhinolaryngol. Ital., 38(4):338-345.
12. Damm M. (2002) IntranasalVolume and Olfactory Function. Chemical Senses, 27(9):831-839.

13. Zhao K., Jiang J., Pribitkin E. et al. (2014) Conductive olfactory losses in chronic chinosinusitis? A computational fluid dynamics study of 29 patients. Int. Forum Allergy Rhinol., 4(4):298-308.

14. Avrunin 0., Nosova Y., Zlepko S. et al. (2019) Assessment of the diagnostic value of the method of computerolfactometry.IIformatyka, Automatyka, Pomiaryw GospodarceiOchronieŚrodowiska, 9(3): 18-21.

15. Oka S., Kawanabe H., Yamanobe S. et al. (2020) Relationship between olfaction and maxillofacial morphology in children with malocclusion. Clin. Experiment. Dent. Res., 7(1):33-39.

16. OlszewskaE,SieskiewizA, Kasackal, Rogowski M,Zukowska M,Soroczyńska J.etal. Cytology of nasal mucosa, olfactometry and rhinomanometry in patients after $\mathrm{CO}$ laser mucotomy in inferiorturbinate hypertrophy. Folia Histochemica et Cytobiologica, 2010; 48(2).

17. Шкорботун В.0., Шкорботун Я.В. (2020) Оцінка якості життяпаціентівз кістами верхньощелепних синусівпісля ендоскопічної синусотомії в залежності від хірургічного доступу. Оториноларингологія, 4(3).

18. Fokkens W., Lund V., Hopkins C. et al. (2020) European Position Paper on Rhinosinusitis and Nasal Polyps 2020. Rhinology J., 58(Suppl. S29): 1-464.

19. Toma S., Hopkins C. (2016) Stratification of SNOT-22 scores into mild, moderate or severe and relationship with other subjective instruments. Rhinology J.,54(2): 129-133.

20. Karlsson A., Persson M., Mjörmheim A. etal. (2020) Total nasal airway resistance while sitting predicts airway collapse when lying down. J. Laryngol. Otol., 134(10):917-924.

21. Moore M., Eccles R. (2012) Normal nasal patency: problems in obtaining standard reference values for the surgeon. J. Laryngol. Otol., 126(6): 563-569.

22. Hinz A., Luck T., Riedel-Heller S. et al. (2018) Olfactory dysfunction: properties of the Sniffin' Sticks Screening 12 testandassociations with quality of life. Eur.Arch. Oto-Rhino-Laryngol., 276(2):389-395.

23. Mann H., Whitney D. (1947) On a Test of Whether one of Two Random Variables is Stochastically Larger than the Other. Ann. Mathem. Stat., 18(1):50-60.

\section{The condition of olfactory function and its impact on the quality of life in patients depending on the disorder of the nasal passages' patency}

\section{v.o. Shkorbotun, M.O. Ovsiienko}

Shupyk national healthcare university of Ukraine, Kyiv, Ukraine

Abstract. An important part in researching of the quality of nasal breathing is determination not only of the quantitative indicators of the air passage through the nose, but also the subjective feelings of satisfaction with nasal breathing. There are cases of impaired quality of life of patients due to sinonasal symptoms with free nasal breathing and air resistance in the nasal passages within normal limits. Objective: to discover the influence of olfactory reception on patients' satisfaction with the quality of life and respiratory function of the nose, depending on the disorder of the nasal passages' patency. Materials and methods. 75 patients who suffered of nasal breathing disorders and/or were dissatisfied with the quality of nasal breathing were examined. All patients were surveyed on the quality of life according to the questionnaire SNOT $=22$, underwent computer rhinomanometry, and olfactometry using Sniffin' Sticks tests. Conclusion. One of the reasons for dissatisfaction with the quality of nasal breathing of patients with normal indicators of total air resistance $\left(\mathrm{R}_{150(\text { tot })}<0.25 \mathrm{~Pa} / \mathrm{cm}^{3} / \mathrm{s}\right)$ may be olfactory receptor dysfunction (hyposmia and anosmia), which is manifested not only by impaired odor recognition and the sharpness of perception, but also a disorder of the formation of patient's subjective feelings of nasal breathing satisfaction and quality of life.

Key words: nasal breathing, olfactory function, dysosmia, rhinomanometry, SNOT-22.

\section{Відомості про авторів:}

Шкорботун Володимир Олексійович — доктор медичних наук, професор, завідувач кафедри оториноларингологїі Національного університету охорони здоров'я України імені П.Л. Шупика, Київ, Україна. Овсієнко Максим Олександрович — аспірант кафедри оториноларингології Національного університету охорони здоров'я України імені П.Л. Шупика, лікар-отоларинголог КНП «Київська міська клінічна лікарня № 9».

\section{Адреса для кореспонденції:}

Шкорботун Володимир Олексійович

04112, Київ, вул. Дорогожицька, 9

E-mail: shent@ukr.net

\section{Information about the authors:}

Shkorbotun Volodymyr 0. — PhD in Medicine, Professor, Head of Department of Otorhinolaryngology of the Shupyk national healthcare university of Ukraine, Kyiv, Ukraine.

Ovsiienko Maxim 0. - PhD student of Department of Otorhinolaryngology of the Shupyk national healthcare university of Ukraine, otolaryngologist of Kyiv clinical hospital № 9, Kyiv, Ukraine. Address for correspondence:

Volodymyr Shkorbotun

04112, Kyiv, Dorogozhytska Str., 9

E-mail: shent@ukr.net 